\title{
Relationship Between Serum BDNF Levels and Cognitive Functions, Cortisol Levels in Depressive Disorder?
}

\author{
Gülfizar Sözeri-Varma1, Yaşar Enli², Emel Aydın¹, Tug̃çe Toker-Ug̃urlu¹, Hüseyin Alaçam¹, \\ Nalan Kalkan-0g̃uzhanog̃lu ${ }^{1}$
}

\section{ÖZET:}

Depresif bozuklukta serum BDNF düzeyleri ile bilișsel işlevler ve kortizol düzeyleri arasındaki ilișki

Amaç: Bu çalışmada, depresif bozuklukta serum BDNF düzeyleri ile bilişsel işlevler ve kortizol düzeyleri arasındaki ilișkinin araştırılması amaçlandı.

Yöntem: Çalışmaya DSM-IV tanı ölçütlerine göre major depresif bozukluk tanısı konulan ve antidepresan ilaç kullanımı olmayan 30 hasta katıldı. Depresyon şiddetinin belirlenmesinde Hamilton Depresyon Deg̃erlendirme ölçeg̃i (HAM-D17) kullanıldı. Serum BDNF düzeyleri ELiSA yöntemi ile belirlendi. Bilișsel işlevlerin deg̃erlendirilmesinde; Sayı dizileri testi, Stroop testi, Sözel bellek süreçleri testi ve Wechsler-görsel bellek alt testleri uyguland.

Bulgular: Hastaların HAM-D17 puan ortalaması 17.09 \pm 4.96 olarak tespit edildi. Serum BDNF düzeyleri ortalama $1453.42 \pm 144.51 \mathrm{pg} / \mathrm{ml}$, serum sabah kortizol düzeyleri $11.54 \pm 4.57 \mu \mathrm{g} / \mathrm{dL}$ olarak belirlendi. HAM-D17 puanları ile BDNF düzeyleri arasında ilișki saptanmadı. Serum BDNF düzeyleri ile kortizol düzeyleri ve nöropsikolojik test puanları arasında ilişki saptanmadı. Serum kortizol düzeyleri ile Stroop testi süre farkı arasında pozitif ilişki tespit edildi ( $\mathrm{s}=0.396 p=0.017)$. Serum kortizol düzeyleri ile dig̃er nöropsikolojik test puanları arasında ilișki saptanmadı.

Sonuç: Çalıșmamızda depresyonu olan hastalarda BDNF düzeyleri ile dikkat ve bellek performansları arasında ilișki bulunmamıştır. Sabah bazal kortizol düzeylerinin yüksek olması dikkati olumsuz yönde etkilemektedir. Serum BDNF düzeyleri ile sabah ölçülen kortizol düzeyleri arasında ilișki saptanmamıştır.

Anahtar sözcükler: depresyon, BDNF (beyin kaynaklı nörotropik faktör), dikkat, bellek, kortizol

Journal of Mood Disorders 2012;2(2):58-65

\section{ABSTRACT:}

Relationship between serum BDNF levels and cognitive functions, cortisol levels in depressive disorder?

Objective: The objective of this study was to examine the relationship between the serum BDNF levels in depressive disorder patients and cognitive functions along with cortisol levels.

Methods: Thirty patients meeting the DSM-IV criteria for major depressive disorder were recruited for this study. Patients had not used any antidepressants. The severity of depression was assessed by the Hamilton Rating of Depression Scale (HAM-D17). Serum BDNF levels were determined by using ELISA. Neuropsychological evaluation included; Digit Span Test, Stroop Test, Verbal Memory Processing Test, and Weschler-Visual Memory.

Results: HAM-D17 scores were $17.09 \pm 4.96$ in patients. Serum BDNF levels were established to be $1453.42 \pm 144.51$ $\mathrm{pg} / \mathrm{mL}$, and mean serum morning cortisol level was established as $11.54 \pm 4.57 \mu \mathrm{g} / \mathrm{dL}$. No relationship was determined between the HAM-D17 scores and BDNF levels. The serum BDNF levels were not correlated with cortisol levels, and neuropsychological tests scores. Serum cortisol levels and Stroop test time differences were established to be positively correlated ( $r s=0.396 p=0.017)$. Serum cortisol levels were not correlated with other neuropsychogical tests.

Conclusion: No relationship was determined between the BDNF levels and attention and memory performances for patients with depression. It was determined that elevated morning baseline cortisol levels affected attention negatively. There was no correlation between serum BDNF levels and morning cortisol levels.

Key words: depression, BDNF (Brain-derived neurotrophic factor), attention, memory, cortisol

Journal of Mood Disorders 2012;2(2):58-65
'Department of Psychiatry, Faculty of Medicine, Pamukkale University, Denizli-Turkey

${ }^{2}$ Department of Biochemistry, Faculty of Medicine, Pamukkale University, Denizli-Turkey

Yazısma Adresi / Address reprint requests to: Dr. Gülfizar Sözeri-Varma, Pamukkale Universitesi Tip Fakultesi, Psikiyatri AD, Doktorlar Cd, No: 42, 20100 Denizli-Turkey

Telefon / Phone: +90-258-444-0728/int:1106

Faks / Fax: +90-258-241-0040

Elektronik posta adresi / E-mail address: e-mail:gvarma@pau.edu.tr

Kabul tarihi / Date of acceptance: 16 Mayıs 2012 / May 16, 2012

Bag̃ıntı beyanı:

G.S.V., Y.E., E.A., T.T.U., H.A., N.K.0.: Yazarla bu makale ile ilgili olarak herhangi bir çıkar çatışması bildirmemișlerdir.

\section{Declaration of interest:}

G.S.V., Y.E., E.A., T.T.U., H.A., N.K.O.: The authors reported no conflict of interest related to this article.

\section{INTRODUCTION}

In recent years, the hypothesis of neuroplasticity which has been put forth concerning the etiopathogenesis of depression is widely accepted. Brain-derived neurotrophic factor (BDNF) is a neurotrophic substance, play a role in the growth and differentiation of immature neurons during the development phase of the brain. It has an impact on dopaminergic, cholinergic, serotonergic and noradrenergic neuron functions, while encouraging neuron survival and protects them against toxicity (1-3). According to the theory of neuroplasticity, depression occurs as a result of altered neuronal plasticity in centers controlling mood $(4,5)$. Patients with major depressive disorder were reported to 
have decreased serum BDNF levels (6,7). It was also pointed out that BDNF levels returned to within the normal range following antidepressant treatment $(7,9,10)$. As a result of a systematic evaluation and metaanalysis study in which 1504 depression patients were examined, it was decided that the treatment of depression is related to neuroplastic changes (11).

Experimental studies have suggested that BDNF has a significant role in learning and memory processes. It also reportedly had an impact on long-term potentiation (LTP) in the hippocampus. BDNF mRNA expression was reported to be associated with memory processes as well (12-14). However, few clinical studies have been conducted to investigate the relationship between BDNF and cognitive impairments in patients with depressive disorder. Impairments in executive functions and cognitive functions such as attention, verbal memory and visuo-spatial memory may be observed in patients with depressive disorder (15). Serum BDNF levels and verbal memory performances were established to be positively correlated in patients with recurrent depression (16). On the other hand, BDNF levels and neurocognitive performance were not established to be correlated in major depressive disorder (17) and patients with bipolar disorder (18). Serum BDNF levels and performances of verbal and visual memory were reported to be negatively correlated in patients with Alzheimer's disease (19).

It has been known that individuals suffering from depression experience an impairment in the diurnal rhythm of cortisol or that alterations in cortisol levels may lead to depressive symptoms $(20,21)$. Baseline serum cortisol secretion and cortisol metabolites increase in patients with depression, leading to impairment in the normal diurnal rhythm of cortisol secretion (21). Morning cortisol levels were reported to be associated with executive dysfunction and memory deficit (22). Schaaf et al. (23) demonstrated a dose-dependent decrease in BDNF mRNA in the hippocampus following the subcutaneous corticosterone injection. In another study, the same authors also established that the decrease in BDNF levels following corticosteroid administration was temporary (24). Previous studies have suggested that cortisol alters BDNF release and effectiveness.

The data we have signify that BDNF plays an important role in memory and learning processes, that the BDNF levels decrease in depressive disorder and that the increase of cortisol level has a negative impact on the BDNF oscillation. The relationship of BDNF that decrease in depressive disorder on memory and attention processes has not yet been studied sufficiently. Our hypothesis is that there is a positive correlation between the serum BDNF levels and neuropsychological test performance in depressive disorder. In this study, the objective was to examine whether there is a relationship between BDNF levels and cognitive functions along with cortisol levels.

\section{METHODS}

\section{Inclusion/Exclusion Criteria}

This study was carried out on patients who applied to the Pamukkale University Faculty of Medicine Psychiatry polyclinic from January 2010 to June 2010 diagnosed with Major Depressive Disorder according to the Diagnostic and Statistical Manual for Mental Disorders Criteria (DSM-IV). A diagnostic assessment was performed to rule out other major Axis I disorders, such as schizophrenia, bipolar disorders, and anxiety disorders. Sociodemographic data forms prepared by the researchers were completed. Following psychiatric examination, the Hamilton Depression Scale (HAM-D, 17 items) was applied by the psychiatrist conducting the examination. Patients who used psychotropic drugs two months prior to the study, had been administered ECT in the preceding six months, displayed psychotic symptoms, or had comorbid psychiatric and neurological diseases were excluded from the study.

A total of 30 patients ( 24 female, $80 \%$; six male, $20 \%$ ) with depression were completed in the present study. On the following day, blood samples were collected from the patients between 8:00 A.M. and 10:00 A.M. to evaluate their serum BDNF and cortisol levels. Cortisol levels were determined at the same time. All blood samples were centrifuged and stored for six months at $-70^{\circ} \mathrm{Cimmediately}$ after collection for the measurement of BDNF. The patients were then administered neuropsychological tests by a trained and experienced psychologist.

Ethics committee approval was obtained from the local ethics committee of Pamukkale University in accordance with the Declaration of Helsinki. Patients were informed about the study, and those who gave written consent were included. 


\section{Hamilton Depression Rating Scale (HAM-D17)}

The Hamilton Depression Rating Scale (HAM-D17) is a 17-item, clinician-administered scale published in 1960 (25). It assesses the level of depression and its change in severity (each item can be scored from 0 to 4 ). The validity and reliability study of the Turkish version of the HAM-D17 was performed by Akdemir et al. (26). A total score of between 0 and 7 indicates no depression; while scores between 8 and 15 indicate mild depression; scores between 16 and 28 indicate moderate depression; and a score greater than 29 indicates severe depression.

\section{Measurement of BDNF and Cortisol Levels}

Serum cortisol concentrations were determined by electrochemiluminescence immunoassay in conjunction with the Elecsys 2010 (Roche Molecular Biochemical Diagnostics, Mannheim, Germany). All blood samples were centrifuged and stored for six months at $-70^{\circ} \mathrm{C}$ immediately after collection for the measurement of BDNF. Analysis of BDNF concentration in the serum was performed with a ChemiKine BDNF Sandwich ELISA

Kit (CHEMICON International, Inc., Temecula, California, USA) according to the manufacturer's instructions. The blood samples were collected with Serum tubes with increased Silica Act Clot Activator. All blood samples were centrifuged within 30 minutes after collection at 1100-1300 rpm for 15 minutes. The samples did not run in duplicate. They were not diluted. Internal controls were used.

\section{Neuropsychological Evaluation WAIS Digit Span Test (DST)}

This digit span test is a subscale of the Wechsler Adult Intelligence Scale-Revised (WAIS-R). The participant is asked to recall a list of numbers or letters in the same order it has been presented in DS-Forwards (DS-FW) This is a direct measure of verbal memory, with few EF connotations. In DS-Backwards (DS-BW), the subject is asked to recall the series backwards. This manipulation requires working memory (27). The total score was established by adding the scores obtained in the two tests. The validity and reliability study of the Turkish version was performed (28).

\section{The Stroop Test}

The Stroop test (Dotrill format) was used to evaluate selective attention, the ability of attentional set shifting, and response inhibition. There were two trials: one in which reading focused on color words printed in different colors, and the other requiring the naming of printed colors. For each part, the completion time and number of errors were recorded (29). The validity and reliability study of the Turkish version was performed (28).

\section{Verbal Memory Processes Test (VMPT)}

This test is a word-list learning test developed by Rey (30). VMPT can differentiate a number of parameters related to memory. Of those, the first is immediate retrieval; the second is the process of learning or acquiring knowledge; and the third is retention of information and recalling. Recalling is evaluated under two categories as delayed spontaneous recalling and delayed recognition memory. The test consists of a list of fifteen unrelated words. The words on the list are read to the subject with an interval of one second between them. The subject is then asked to recall the words. This stage of the test offers information regarding immediate retrieval and sustained attention. The number of words recalled correctly provides the Immediate Memory Score. After the first attempt, the same list is read to the subject nine more times, repeating the recalling process after each time. This stage provides information regarding the learning skills of the subject. The validity and reliability study of the Turkish version of VMPT was performed (31).

\section{Wechsler Memory Scale - Visual Memory Test (VMT)}

This was developed by Wechsler in 1987 (32). It is used in assessing visual learning and memory functions. The subject is shown four cards, each with a different design, for a certain period (15 s) following a certain order before being concealed. The subject is then asked to draw those figures. The subject is asked to draw the same figures once again 40 minutes later. The evaluation provides scores for immediate recall and delayed spontaneous recall. 


\section{Statistical Analysis}

Statistical analyses were carried out using SPSS 10.0 software. Besides deŞnitive statistical methods, a nonparametric Mann-Whitney U test was applied for comparing the quantitative data of the Şrst episode with patients who had recurrent depressive episode. It was controlled if numeric data displayed normal distribution or not via Kolmogorov-Smirnov test. It was determined that scores of HAM-D17 and cortisol levels displayed normal distribution whereas BDNF level and neuropsychological test points did not. Statistical analyses were carried out using Spearsman correlation analysis. $\mathrm{P}<0.05$ was accepted to be statistically significant.

\section{RESULTS}

Sociodemoghraphic characteristics, scores of HAM-D17, BDNF levels and morning serum cortisol levels are given in Table 1. No relationship between the BDNF

\section{Table 1: Sociodemographic characteristics and measures}

\begin{tabular}{ll} 
Variable & Mean \pm SD \\
\hline Age & $39.75 \pm 16.26$ \\
Education year & $8.53 \pm 3.86$ \\
HAM-D17 & $17.09 \pm 4.96$ \\
Number of depressive episode & $1.40 \pm 0.73$ \\
Level of BDNF & $1453.42 \pm 144.51 \mathrm{ng} / \mathrm{ml}$ \\
Level of cortisol & $11.54 \pm 4.57 \mu \mathrm{gl} / \mathrm{dL}$ \\
\hline
\end{tabular}

HAM-D17: Hamilton Depression Rating Scala, BDNF: Brain Derived Neurotrophic Factor levels and the HAM-D17 total score was determined ( $\mathrm{rs}=0.355, \mathrm{p}>0.05)$. BDNF levels were not correlated with cortisol levels ( $r s=0.163, p>0.05$ ). The serum BDNF levels were not correlated with scores of neuropsychological tests (Table 2). The serum cortisol levels had a weak-moderate positive correlation with Stroop Test time differences ( $\mathrm{rs}=0.396, \mathrm{p}=0.017$ ). No correlation was established between the serum cortisol levels and the scores of the DST, VMPT, WMS-Visual Memory Test (Table 2).

There was no difference between the age, years of education, serum BDNF levels and cortisol levels for those with single episode $(\mathrm{n}=22)$ and recurrent episode $(n=8)$ (for all, $p>0.05)$. For patients with recurrent depression, the time difference score of Stroop test was determined to be significantly higher in comparison to those with a single episode (respectively, 64.16 \pm 16.11 , 40.83 $\pm 13.93, \mathrm{z}=2.896, \mathrm{p}=0.002$, Mann Whitney U test). No difference was determined between the DST, VMPT, WMS-Visual Memory Test scores of the two groups ( $>0.05$ for all).

\section{DISCUSSION}

The majority of the participants in our study were middle age females and none of them used any medication. In our study no relationship was determined between the serum BDNF levels and depression severity. No difference was determined in the BDNF levels of those with single episode and recurrent episode. In another study that we carried out, the serum BDNF levels of

\section{Table 2: The relationship BDNF and scores of neuropsyhological test and cortisol levels}

\begin{tabular}{|c|c|c|c|}
\hline Neuropsyhological test & Mean \pm SD & rs $^{1}$ & rs $^{2}$ \\
\hline \multicolumn{4}{|l|}{ Digit Span Test } \\
\hline forwards & $4.75 \pm 1.57$ & 0.200 & 0.027 \\
\hline backward & $4.58 \pm 2.63$ & 0.560 & 0.140 \\
\hline \multicolumn{4}{|l|}{ Stroop Test } \\
\hline time difference & $51.29 \pm 25.03$ & 0.066 & $0.396 *$ \\
\hline \multicolumn{4}{|l|}{ Verbal Memory Processes Test } \\
\hline short term memory & $5.30 \pm 1.71$ & 0.218 & 0.194 \\
\hline score of learning & $105.53 \pm 27.13$ & 0.109 & 0.016 \\
\hline maximum learning & $13.64 \pm 2.11$ & 0.160 & 0.099 \\
\hline long term memory recall & $11.57 \pm 3.93$ & 0.141 & 0.124 \\
\hline long term memory recognition & $2.28 \pm 1.90$ & 0.035 & 0.212 \\
\hline \multicolumn{4}{|l|}{ WMS -Visual Memory Test } \\
\hline copy & $8.25 \pm 3.18$ & 0.176 & 0.031 \\
\hline recall & $6.74 \pm 3.02$ & 0.062 & 0.065 \\
\hline
\end{tabular}

rs ${ }^{1}$ : correlation BDNF levels and neuropsychological tests, Spearsman correlation analysis, for all $p>0.05$.

$\mathrm{rs}^{2}$ : correlation cortisol levels and neuropsychological tests, Spearsman correlation analysis, " $p<0.05$, the others $p>0.05$. 
depression patients were determined to be lower than those of the healthy control group (33). Similar to our results, there are studies stating that there is no relationship between serum BDNF levels and the severity or the recurrent nature of depression $(34,35)$. However, some studies state that there is a negative correlation between depression severity and serum BDNF levels $(8,36,37)$. Dell'Osso et al. (38) reported that a negative correlation was determined between serum BDNF levels and both HAM-D total score and the retardation factor score of the HAM-D. It was determined that the BDNF levels were lower in patients with recurrent depression, dissociative symptoms and sleep irregularity, and in patients with a high disorder severity. This study suggests a relationship between BDNF levels and the severity of depression and different depressive symptoms. Severity of depression in our sample was mild/moderate level. This situation may have influenced our results. New studies are required which try to determine the relationship between BDNF levels and depressive symptomatology and depression severity.

The neuropsychological test scores of our patients were examined according to the standard scores of the applied tests (28). It was observed that in relation with the attention problems, the patients had difficulties in immediate memory and that the long term memory and learning performances were within normal limits. In the studies carried out, it has been stated that attention and short term memory are negatively affected in depression (39); that attention, executive functions, visual spatial memory and learning were affected negatively (40) along with episodic memory and that mental flexibility decreased (41). In our study, it was not found that the relationship between serum BDNF levels and the neuropsychological test scores. Few studies investigated the relationship between serum BDNF levels and cognitive functions in patients with depression. In the study carried out by Oral et.al. (17), it has been determined that the executive functions, short and long term memory, working memory and attention performances of depression patients were lower than those of the healthy control group. However, no correlation has been determined between this decrease and the serum BDNF levels. Only, a negative correlation has been determined between the BDNF levels and the Trail Making Test-part B scores. It has been suggested that there might be a relationship between BDNF and prefrontal functions. Hovewer, it have indicated that the BDNF levels and being neglected during childhood have a negative affects on memory functions. The same study also maintained depressed BDNF levels to be a predictor of impaired immediate verbal recall, concluding that BDNF levels played a critical role in depression and verbal memory performance, particularly with encoding processes (16).

Memory is studied as short and long term memory in terms of time and explicit, declerative and implicit, nondeclerative memory in terms of content. It is stated that in depression there are no implicit memory problems due to the fact that the automatic processes are not affected. Explicit memory requires a recollection and the limbic system containing the hippocampus structures play an important role (42). The tests applied in our study give information about attention and working memory as well as short and long term memory with regards to time and explicit memory functions with regards to content. Memory and learning is a process concerning many areas and different neurotransmitters such as dopamine, asetilcholine, glutamate in the brain. Short term or working memory is related with the parietal cortex and the prefrontal cortex, the coding and consolidation of information is related with the limbic system, storage with the cortex and the recalling of information is related with the prefrontotemporopolar networks (43). Even though BDNF plays a role in the storage of memories at different regions of the brain, it is especially important for the hippocampus related learning processes (44). Effects of BDNF deficiency may have been compensated by other neurotransmitters and networks. Studies that examine the relationship between memory processes and BDNF in depression are required.

The current study established a negative correlation between cortisol levels and Stroop test time differences. This particular result suggested that depressed patients with elevated morning cortisol levels had poorer attention performances. However, the present study also demonstrated that morning baseline cortisol level had no impact on verbal and visual memory processes. A study investigating the relationship between verbal memory processes and hippocampal volume and plasma or urinary free cortisol levels in patients with depression obtained similar results. The patients with depression were reported with significantly more severe memory impairment (visual 
memory, attention, vigilance, or distractibility) when compared with the healthy controls in that study. However, cortisol levels were not established to be correlated with hippocampal volume or verbal memory processes (45).

Certain studies demonstrated patients with elevated serum cortisol levels, and associated higher cortisol levels with poorer neurocognitive test performances, including verbal/visual memory, working memory and attention processes in depression $(46,47)$. The association between baseline cortisol levels measured at different times of the day and cognitive functions have been investigated in some studies. Hinkelman et al. (48) established elevated morning baseline cortisol levels to have a negative impact on cognitive functions such as verbal memory, visuospatial memory, working memory and selective attention. Gomez et al. (49) compared serum cortisol levels measured betweenthehoursof 18:00and09:00andneuropsychological test performances of major depression patients with and without psychotic symptoms and healthy controls. Patients with psychotic symptoms were observed with more severe impairment in terms of simple verbal attention compared to those without psychotic symptoms. Cortisol levels measured between the hours of 18:00 and 01:00 in patients with psychotic symptoms were established to be correlated with poorer verbal memory and psychomotor speed performance. Those studies have suggested that neuropsychological test performances may vary in different subtypes of depression (such as with and without psychotic symptoms), and cortisol levels measured at different times of the day may have varying effects on cognitive functions. Further studies investigating the impact of cortisol levels at different times of the day on cognitive functions by taking into consideration the diurnal cortisol rhythm carried out with a large study sample, including various depression subtypes and healthy controls, may help elucidate this particular issue.

No correlation was established between serum BDNF and cortisol levels in our study. A similar study measured serum BDNF and cortisol levels in patients with depression before the administration of therapy and compared them with post-treatment values. Neither pre- nor posttreatment serum BDNF and cortisol levels were established to be correlated (50). Corticosterones inhibit the mRNA expression of BDNF in the hippocampus, and the activation of mineralocorticoid and glucocorticoid receptors decrease the transcriptional activity in the BDNF promoter region. It was also suggested that different doses (high or low) of corticosteroid levels might have different effects on the BDNF expression in the hippocampus (23). Another study carried out with rats (water-labyrinth problem) revealed that although corticosteroid levels increased while learning a new task, BDNF expression remained uninhibited in certain regions of the hippocampus. Elevated BDNF expression in specific hippocampal regions was observed to be correlated with good memory performance. It was postulated that hippocampal BDNF expression could be resistant to inhibition through corticosteroids (51). Data obtained particularly in preclinical/experimental trials suggested that cortisol could have an impact on BDNF production and effectiveness. Further clinical studies are needed to investigate the relationship between BDNF and cortisol.

Levels of serum BDNF decrease with stress $(52,53)$ and increase with exercise (54). In a study examining the factors affecting BDNF levels, 1168 people with no psychiatric disorder and antidepressant usage were examined. It was determined that the BDNF levels were affected by 8 factors which are the time of blood withdrawal, storage, urbanicity, age, sex, smoking status and food and alcohol intake (55). In our study, none of the patients consumed alcohol or addictive substances however factors such as food consumption and exercise could not be controlled. These factors should be taken into account when evaluating our results.

The lack of a control group and a limited number of patients were the constraints of this current study. Our patient sample consisted of mild/moderately depressed patients not undergoing antidepressant drug treatment. These outpatient did not demonstrate psychotic symptoms. Therefore, our results have to be confirmed in a larger sample consisting of different depression subtypes, patients with psychotic symptoms and those with severe major depressive disorder.

\section{CONCLUSION}

Our results indicate that in depression the serum BDNF levels are not related to the neuropsychological tests performances. And no correlation existed between serum BDNF and cortisol levels. However we known that BDNF plays an important role in learning and memory processes. Cognitive functions such as attention, verbal 
memory, visual memory and working memory are impairment in major depressive disorder. The relationship between BDNF and cognitive impairments must further investigate in major depressive disorder.

\section{References:}

1. Frechilla D, Insausti R, Ruiz-Golvano P, García-Osta A, Rubio MP, Almendral JM, Del Río J. Implanted BDNF-producing fibroblasts prevent neurotoxin-induced serotonergic denervation in the rat striatum. Brain Res. Mol Brain Res 2000;76:306-14.

2. D'sa C, Duman RS. Antidepressants and neuroplasticity. Bipolar Disord 2002;4:183-94.

3. Palizvan MR, Sohya K, Kohara K Maruyama A, Yasuda H, Kimura F, Tsumoto T. Brain-derived neurotrophic factor increases inhibitory synapses, revealed in solitary neurons cultured from rat visual cortex. Neuroscience 2004;126:955-66.

4. Nestler EJ, Barrot M, Dileone RJ, Eisch AJ, Gold SJ, Monteggia LM. Neurobiology of depression. Neuron 2002;34:13-25.

5. Aydemir O, Deveci A. BDNF Measurement in Stress-Related Mood Disorders: A Review of Clinical Studies. Turk Psikiyatri Derg 2009;20:385-39.

6. Monteleone P, Serritella C, Martiadis V, Maj M. Decreased levels of serum brain-derived neurotrophic factor in both depressed and euthymic patients with unipolar depression and in euthymic patients with bipolar I and II disorders. Bipolar Disorders 2008; 10:95-100.

7. Lee B-H, Kim Y-K. Reduced platelet BDNF level in patients with major depression. Prog Neuro-Psychopharmacol Biol Psychiatry 2009;33:849-53

8. Gonul AS, Akdeniz F, Taneli F, Donat O, Eker Ç, Vahip S. Effect of treatment on serum brain-derived neurotrophic factor levels in depressed patients. Eur Arch Psychiatry Clin Neurosci 2005;255:381-386.

9. Aydemir C, Yalcin ES, Aksaray S Kisa C, Yildirim SG, Uzbay T, Goka E. Brain-derived neurotrophic factor (BDNF) changes in depressed women. Progress in Neuro-Psychopharmacology \& Biological Psychiatry 2006;30:1256-60.

10. Aydemir O, Deveci A, Taneli F. The effect of chronic antidepressant treatment on serum brain-derived neurotrophic factor levels in depressed patients: a preliminary study. Prog. Neuropsychopharmacol. Biol. Psychiatry 2005;29:261-5.

11. Brunoni AR, Lopes M, Fregni F. A systematic review and metaanalysis of clinical studies on major depression and BDNF levels: implications for the role of neuroplasticity in depression. Int $\mathrm{J}$ Neuropsychopharmacol 2008;11: 1169-80.

12. Figurov A, Pozzo-Miller LD, Olafsson P, Wang T, Lu B. Regulation of synaptic responses to high-frequency stimulation and LTP by neurotrophins in the hippocampus. Nature 1996;381:706-9.

13. Schaaf MJ, Workel JO, Lesscher HM, Vreugdenhil E, Oitzl MS, De Kloet ER. Correlation between hippocampal BDNF mRNA expression and memory performance in senescent rats. Brain Res 2001;915:227-33.

\section{Acknowledgements}

The study was supported by Pamukkale University (Scientific Research Projects Coordination Unit).

14. Kiyofumi Y, Makoto M, Toshitaka N. Role for brain-derived neurotrophic factor in learning and memory. Life Sciences 2002;70:735-44.

15. McDermott LM, Ebmeier KP. A meta-analysis of depression severity and cognitive function. J Affect Disord 2009;119:1-8.

16. Grassi-Oliveira R, Stein LM, Lopes RP, Teixeira AL, Bauer ME. Low plasma brain-derived neurotrophic factor and childhood physical neglect are associated with verbal memory impairment in major depression-a preliminary report. Biol Psychiatry 2008;64:281-5.

17. Oral E, Canpolat S, Yildirim S, Gulec M, Aliyev E, Aydin N.Cognitive functions and serum levels of brain-derived neurotrophic factor in patients with major depressive disorder. Brain Res Bull. 2012, doi:10.1016/j.brainresbull.2012.03.005.

18. Dias VV, Brissos S, Frey BN, Andreazza AC, Cardoso C, Kapczinski F. Cognitive function and serum levels of brain-derived neurotrophic factor in patients with bipolar disorder. Bipolar Disord. 2009;11:663-71.

19. O’bryant SE, Hobson VL, Hall JR. Barber RC, Zhang S, Johnson L, Diaz-Arrastia R; Texas Alzheimer's Research Consortium. Texas Alzheimer's Research Consortium: Serum brain-derived neurotrophic factor levels are specifically associated with memory performance among Alzheimer's disease cases. Dement Geriatr Cogn Disord. 2011;31:31-6.

20. Swaab DF, Bao AM, Lucassen PJ. The stress system in the human brain in depression and neurodegeneration. Ageing Res Rev 2005;4:141-94.

21. Musselman DL, Nemeroff CB. Depression and endocrine disorders: focus on the thyroid and adrenal system. Br J Psychiatry Suppl. 1996;30:123-8.

22. Egeland J, Lund A, Landr NI Rund BR, Sundet K, Asbjørnsen A, Mjellem N, Roness A, Stordal KI. Cortisol level predicts executive and memory function in depression, symptom level predicts psychomotor speed. Acta Psychiatr Scand 2005;112:434-41.

23. Schaaf MJ, Hoetelmans RW, De Kloet ER, Vreugdenhil E. Corticosterone regulates expression of BDNF and trkB but not NT-3 and trkC mRNA in the rat hippocampus. J Neurosci Res 1997;48:334-41.

24. Schaaf MJ, De Jong J, De Kloet Er, Vreugdenhil E. Downregulation of BDNF mRNA and protein in the rat hippocampus by corticosterone. Brain Res. 1998;813: 112-20.

25. Hamilton MA. Rating scale for depression. J Neurol Neurosurg Psychiatry 1960;23:56-62

26. Akdemir A, Türkçapar M H, Orsel SD, Demirergi N, Dag I, Ozbay M H Reliability and validity of the Turkish version of the Structured Interview Guide For Hamilton Depression Rating Scale. Comprehensive Psychiatry 2001; 42: 161-165. 
27. Wechsler D. Wechsler adult intelligence scale-revised. The Psychological Corporation: 1981, New York.

28. Karakaş S. BİLNOT Bataryası El Kitabı: Nöropsikolojik Testler İçin Araştırma ve Geliştirme Çalışmaları. (2. Baskı). Ankara. Eryılmaz Ofset Matbaacılık Gazetecilik, 2006.

29. Stroop JR. The basis of ligons theory. American Journal of Psychology 1935;47:499-504.

30. Rey A. Lexamen clinique en psychologie. Presse Universitaire de France, 1964, Paris, France.

31. Oktem O. A verbal test of memory processes: A preliminary Study. Archives of Neuropsychiatry 1992;29:196-206.

32. Wechsler D: Wechsler Memory Scale- Revised. (The Psychological Corporation): 1987, New York.

33. Sözeri-Varma G, Enli Y, Toker-Uğurlu T, Alaçam H, KalkanOğuzhanoğlu N. Decreased serum BDNF levels in major depressive patients. Neurology, Psychiatry and Brain Research 2011;17: 84-88.

34. Molendijk ML, Bus BA, Spinhoven P, Penninx BW, Kenis G, Prickaerts J, Voshaar RC, Elzinga BM. Serum levels of brainderived neurotrophic factor in major depressive disorder: statetrait issues, clinical features and pharmacological treatment. Mol Psychiatry. 2011;16:1088-95. doi: 10.1038/mp.2010.98.

35. Jevtović S, Karlović D, Mihaljević-Peleš A, Šerić V, Vrkić N, Jakšić N. Serum Brain-derived neurotrophic factor (BDNF): the severity and symptomatic dimensions of depression. Psychiatr Danub. 2011;23:363-9.

36. Shimizu E, Hashimoto K, Okamura N. Koike K, Komatsu N, Kumakiri C, Nakazato M, Watanabe H, Shinoda N, Okada S, Iyo $\mathrm{M}$. Alterations of serum levels of brain-derived neurotrophic factor (BDNF) in depressed patients with or without antidepressants. Biol. Psychiatry 2003;54:70-5.

37. Satomura E, Baba H, Nakano Y, Maeshima H, Suzuki T, Arai $\mathrm{H}$. Correlations between brain-derived neurotrophic factor and clinical symptoms in medicated patients with major depression. J Affect Disord. 2011;135:332-5.

38. Dell'osso L, Del Debbio A, Veltri A, Bianchi C, Roncaglia I, Carlini M, Massimetti G, Catena Dell'Osso M, Vizzaccaro C, Marazziti D, Piccinni A. Associations between brain-derived neurotrophic factor plasma levels and severity of the illness, recurrence and symptoms in depressed patients. Neuropsychobiology 2010;62: 207-12.

39. Williams RA, Hagerty BM, Cimprich B, Therrien B, Bay E, Oe $\mathrm{H}$. Changes in directed attention and short-term memory in depression Journal of Psychiatric Research 2000;227-238.

40. Porter RJ, Gallagher P, Thompson JM, Young AH. Neurocognitive impairment in drug-free patients with major depressive disorder. British Journal of Psychıatry 2003;182:214-220.
41. Airaksinen E, Larsson M, Lundberg I, Forsell Y. Cognitive functions in depressive disorders: evidence from a population-based study. Psychol Med. 2004;34:83-91.

42. Karabekiroğlu K, Gımzal A, Berkem M. Psikiyatrik bozukluklarda bellek sorunları Anatolian Journal of Psychiatry 2005;6:188-196

43. Özen NE, Rezaki M. Prefrontal Korteks: bellek işlevi ve bunama ile ilişkisi. Türk Psikiyatri Dergisi 2007;18:262-269.

44. Bekinschtein P, Cammarota M, Izquierdo I, Medina JH. BDNF and memory formation and storage. Neuroscientist 2008;14:147-56.

45. Vythilingam M, Vermetten E, Anderson GM, Luckenbaugh D, Anderson ER, Snow J, Staib LH, Charney DS, Bremner JD.Hippocampal volume, memory, and cortisol status in major depressive disorder: effects of treatment. Biol Psychiatry 2004;56:101-12.

46. Rubinow DR, Post RM, Savard R, Gold PW. Cortisol hypersecretion and cognitive impairment in depression. Arch Gen Psychiatry 1984;41:279-83.

47. Greendale GA, Kritz-Silverstein D, Seeman T, Barrett-Connor E. Higher basal cortisol predicts verbal memory loss in postmenopausal women: Rancho Bernardo Study. J Am Geriatr Soc. 2000;48:1655-8.

48. Hinkelmann K, Moritz S, Botzenhardt J Riedesel K, Wiedemann K, Kellner M, Otte C. Cognitive impairment in major depression: association with salivary cortisol. Biol Psychiatry. 2009;66:879-85.

49. Gomez RG, Fleming SH, Keller J, Flores B, Kenna H, DeBattista C, Solvason B, Schatzberg AF. The neuropsychological profile of psychotic major depression and its relation to cortisol. Biol Psychiatry 2006;60:472-8.

50. Büyükışık NS. Brain Derived Neurotrophic Factor Levels Before And After Treatment in Patients with Major Depression (Uzmanlık tezi) Istanbul, 2008.

51. Schaaf MJ, De Kloet ER, Vreugdenhil E. Corticosterone effects on BDNF expression in the hippocampus. Implications for memory formation. Stress 2000;3:201-8.

52. Smith MA, Makino S, Kim SY, Kvetnansky R. Stress increases brain-derived neurotropic factor messenger ribonucleic acid in the hypothalamus and pituitary. Endocrinology 1995;136:3743-50.

53. Kuipers SD, Trentani A, Den Boer JA, Ter Horst GJ. Molecular correlates of impaired prefrontal plasticity in response to chronic stress. J. Neurochem 2003;85:1312-23.

54. Gustafsson G, Lira CM, Johansson J Wisén A, Wohlfart B, Ekman $\mathrm{R}$, Westrin A. The acute response of plasma brain-derived neurotrophic factor as a result of exercise in major depressive disorder. Psychiatry Res 2009;169:244-8.

55. Bus BA, Molendijk ML, Penninx BJ Buitelaar JK, Kenis G, Prickaerts J, Elzinga BM, Voshaar RC. Determinants of serum brain-derived neurotrophic factor. Psychoneuroendocrinology. 2011;36:228-39. 